\title{
The Influence of Learning Motivation and Teacher's Teaching Style on Student Achievement (At MA Muhammadiyah)
}

\author{
Kharisma Danang Yuangga \\ Universitas Pamulang \\ E-mail: danangyuangga@gmail.com
}

(Received: December-2018; Reviewed: January-2019; Accepted: February-2019;

Avalaibel Online: February-2019; Published: March-2019)

(7) (\$) This is an open access article distributed under the Creative Commons Attribution License CC-BY-NC-4.0 @2019 by author (https://creativecommons.org/licenses/by-nc/4.0/)

\begin{abstract}
How to teach teachers more or less will motivate students to absorb knowledge. The purpose of this study was to determine the effect of learning motivation and teaching style on student achievement in the MA Muhammadiyah. The method used is descriptive method with an associative approach. The sampling technique used was proportional random sampling using a sample of 76 respondents. The analysis tool uses validity test, reliability test, classic assumption test, regression analysis, correlation coefficient analysis, coefficient of determination analysis and hypothesis testing. The results of this study are Learning Motivation has a positive and significant effect on student learning achievement by $42.7 \%$. hypothesis testing is obtained $t_{\text {count }}>t_{\text {table }}$ or $(7.428>1.993)$, so that $\mathrm{H} 0$ is rejected and $\mathrm{H} 1$ is accepted, meaning that there is a positive and significant influence between learning motivation on student learning achievement at the MA Muhammadiyah Office. Teacher teaching style has a positive and significant effect on student learning achievement by $36.0 \%$. Hypothesis testing is obtained $t_{\text {count }}>t_{\text {table }}$ or $(6.454>$ 1.993) so that $\mathrm{H} 0$ is rejected and $\mathrm{H} 2$ is accepted meaning that there is a positive and significant influence between the teacher's teaching style on student learning achievement on. A simultaneous test of teacher motivation and teaching style has a positive and significant effect on student learning achievement with an influence contribution of $48.4 \%$, while the remaining $52.0 \%$ is influenced by other factors. Hypothesis testing obtained the value of $F_{\text {count }}>F_{\text {table }}$ or (39.505> 2.730), thus Ho is rejected and $\mathrm{H} 3$ is accepted. This means that there is a positive and significant effect simultaneously between learning motivation and teacher teaching style on student achievement in the MA Muhammadiyah
\end{abstract}

Keywords: Learning motivation, teacher teaching style, student learning achievement.

\section{INTRODUCTION}

In the learning process can use appropriate methods and tools and pay attention to teaching styles that are suitable for students, student learning outcomes will be good (Azhar, 2008; Hernawan, Permasih, \& Dewi, 2008; Prasetya \& Ahmadi, 2005; S.Winataputra, 2006; Sudrajat, 2015; Yaumi, 2018). The success of education in these students is very dependent on the 
professionalism of teachers in carrying out their duties as a mediator of science in the classroom (Hamid, 2017; Hendri, 2010; Kartowagiran, 2006; Laelasari, 2013; Shabir, 2009). Likewise with the motivation to learn which is no less important to determine learning achievement. How to teach teachers more or less will motivate students to absorb knowledge (Arhas, 2018; Hamdu \& Agustina, 2011; Idzhar, 2016) This directly will have an impact on student achievement. Teaching and learning activities and learning motivation always get special attention for those who learn and teach.

Teachers as educators and instructors are the determining factors for the success of any educational endeavor (Rusman, 2012; Saragih, 2008; Yuslaini, 2012). The teacher as a role model for his students, a student will pay attention then imitate what his teacher does (Hamid, 2017; Suyanto \& Jihad, 2013; Westri Setyo Lestari1, Herawati Susilo2, 2017). The low quality of the teacher's style of teaching turns out to have negative implications for students, such as a lack of motivation and creativity of students in learning so as to cause low physics learning achievement. Learning achievement is the result achieved by someone after obtaining a process to get changes in behavior both cognitive, affective and psychomotor (Qayyum, Akib, \& Darwis, 2019; Suprianto, Arhas, \& Salam, 2018). The success of an educational institution can be seen from the results of student achievement. High learning achievement gives meaning to success in the learning process that has been outlined in the goal of national education which is to educate the nation's life. Each student has different abilities and characters to be able to receive the subject matter delivered by the teacher. A student who is accustomed to applying a deep learning approach (depth) for example, may be more likely to achieve quality learning achievement than students who use a surface learning approach (outward). The problem that is often encountered by a teacher is that when learning activities take place there are students who are sleepy, engrossed in gadgets and play with their peers so that what is explained by the teacher cannot be well received.

\section{METHOD}

The type of data used is quantitative with primary data sources by distributing questionnaires which are then carried out tabulation and feasibility analysis as well as secondary data from the various scientific literature. The population in this study were MA Muhammadiyah students, totaling 310 students. Sampling was used Slovin (Hidayat, 2017) formula technique with an error rate of $10 \%$ to obtain a sample of 76 students. The instrument testing uses validity and reliability tests. From the validity and reliability test stated valid and reliable, this is evidenced by the value of $r_{\text {count }}>r_{\text {table }}$, likewise, the instrument used is appropriate and feasible to be forwarded to the next test. The classic assumption test used is; normality testing using Kolmogorov Smirnov obtained a significance greater than 0.50 and thus declared normal; Multicollinearity testing obtained tolerance values $<1$ and VIF $<10$ so that it was concluded there was no interference with multicollinearity; autocorrelation testing obtained the value of Durbin-Watson at an interval of 1.550 - 2.460, thus this regression model does not have autocorrelation; heteroscedasticity testing with Glejser test obtained significance values greater than 0.05 so it was concluded that there was no interference with heteroscedasticity.

\section{RESULT AND DISCUSSION}

\section{Descriptive Analysis}

The criteria of the object under study are based on respondents' responses to the question items about the variable learning motivation (X1), teacher teaching Style (X2) and student learning achievement (Y) as follows: 
Table 1

Descriptive Score of Respondents' Answers

\begin{tabular}{lr|r|r|r|r}
\hline \multicolumn{7}{c}{ Descriptive Statistics } \\
\hline & N & Minimum & Maximum & \multicolumn{1}{c}{ Mean } & Std. Deviation \\
\hline Learning Motivation (X1) & 76 & 32 & 47 & 38.18 & 3.719 \\
\hline Teacher Teaching Style (X2) & 76 & 30 & 49 & 38.82 & 4.384 \\
\hline Student Learning Achievement (Y) & 76 & 31 & 46 & 39.18 & 3.606 \\
\hline Valid N (listwise) & 76 & & & & \\
\hline
\end{tabular}

Learning motivation data obtained results of a minimum variance score of 32 and a maximum score of 47 and a ratting mean score of 38.18 and a standard deviation level of 3.719 . Teacher teaching style data obtained a minimum variance score of 30 and a maximum score of 49 and a ratting mean score of 38.82 and a standard deviation level of 4.384. Student learning achievement data obtained results of a minimum variance score of 31 and a maximum score of 46 and a ratting mean score of 39.18 and a standard deviation level of 3.606 .

\section{Verification Analysis}

Verification analysis is intended to determine the magnitude of the influence and analyze the significance of the influence. In this analysis carried out on the influence of two independent variables on the dependent variable. partially or simultaneously.

This multiple regression test is intended to find out how much influence X1 and X2 variables have on the Y variable. In this study motivation learning (X1) and teacher's teaching style (X2) on student learning achievement (Y). The following are the results of processed regression data with SPSS version 26 which can be seen in the following table:

Table 2.

Results of Multiple Regression Processing Variables Learning Motivation (X1) and Teacher Teaching Style (X2) Against Student Learning Achievement (Y)

\section{Coefficients $^{\mathrm{a}}$}

\begin{tabular}{|c|c|c|c|c|c|c|}
\hline \multirow{2}{*}{\multicolumn{2}{|c|}{ Model }} & \multicolumn{2}{|c|}{$\begin{array}{c}\text { Unstandardized } \\
\text { Coefficients }\end{array}$} & \multirow{2}{*}{$\begin{array}{l}\text { Standardized } \\
\text { Coefficients } \\
\text { Beta }\end{array}$} & \multirow[b]{2}{*}{$\mathrm{t}$} & \multirow[b]{2}{*}{ Sig. } \\
\hline & & $\mathrm{B}$ & Std. Error & & & \\
\hline \multirow[t]{3}{*}{1} & (Constant) & 10.474 & 3.248 & & 3.225 & .002 \\
\hline & Learning Motivation (X1) & .454 & .092 & .468 & 4.926 & .000 \\
\hline & Teacher Teaching Style (X2) & .293 & .078 & .357 & 3.753 & .000 \\
\hline
\end{tabular}

a. Dependent VariableStudent Learning Achievment (Y)

Based on the results of the regression calculations in the above table, the regression equation $\mathrm{Y}$ $=10.474+0.454 \mathrm{X} 1+0.293 \mathrm{X} 2$ can be obtained. A constant value of 10.474 means that if the learning motivation (X1) and teacher teaching style (X2) variables are missing then there is a student learning achievement $(\mathrm{Y})$ value of 10.474 points. A value of 0.454 is interpreted if the constant is constant and there is no change in the teacher teaching style variable (X2), then every 1 unit change in the learning motivation variable (X1) will result in a change in Student learning achievement $(\mathrm{Y})$ of 0.454 points. A value of 0.293 is interpreted if the constant is constant and there is no change in the learning motivation variable (X1), then every 1 unit change in the variable teacher teaching style (X2) will result in a change in student learning achievement (Y) of 0.293 points. 
Analysis of the coefficient of determination is intended to determine the percentage of the contribution of influence between the independent variables on the dependent variable both partially and simultaneously), in this study the variables of learning motivation (X1) and teacher teaching style (X2) on student learning achievement (Y). Here are the results of the calculation of the coefficient of determination, as follows:

Table 3.

Partial Determination Coefficient Analysis Results Between Learning Motivation (X1) Against Student Learning Achievement (Y)

\begin{tabular}{|c|c|c|c|c|}
\hline \multicolumn{5}{|c|}{ Model Summary } \\
\hline Model & $\mathrm{R}$ & R Square & $\begin{array}{c}\text { Adjusted R } \\
\text { Square }\end{array}$ & $\begin{array}{l}\text { Std. Error of the } \\
\text { Estimate }\end{array}$ \\
\hline 1 & $.654^{\mathrm{a}}$ & .427 & .419 & 2.748 \\
\hline
\end{tabular}

Based on the test results in the table above, R-Square value or determination of 0.427 is obtained, this shows that the contribution of influence between learning motivation to student learning achievement is $42.7 \%$, while the remaining $57.3 \%$ is influenced by other factors not examined.

Table 4

Partial Determination Coefficient Analysis Results Between Teacher Teaching Style (X2) Against Student Learning Achievement (Y)

\begin{tabular}{|c|c|c|c|c|}
\hline \multicolumn{5}{|c|}{ Model Summary } \\
\hline Model & $\mathrm{R}$ & R Square & $\begin{array}{c}\text { Adjusted R } \\
\text { Square }\end{array}$ & $\begin{array}{l}\text { Std. Error of the } \\
\text { Estimate }\end{array}$ \\
\hline 1 & $.600^{a}$ & .360 & .351 & 2.904 \\
\hline
\end{tabular}

a. Predictors: (Constant), Teacher Teaching Style (X2)

Based on the test results in the table above, R-Square value or determination of 0.360 is obtained, this shows that the contribution of the influence between teacher's teaching style to student learning achievement is $36.0 \%$, while the remaining $64.0 \%$ is influenced by other factors that are not researched.

Table 5

Results of Simultaneous Determination Coefficient Analysis between Learning Motivation (X1) and Teacher's Teaching Style (X2) Against Student Learning Achievement (Y)

\begin{tabular}{|c|c|c|c|c|}
\hline \multicolumn{5}{|c|}{ Model Summary } \\
\hline Model & $\mathrm{R}$ & R Square & $\begin{array}{c}\text { Adjusted R } \\
\text { Square }\end{array}$ & $\begin{array}{l}\text { Std. Error of the } \\
\text { Estimate }\end{array}$ \\
\hline 1 & $.721^{\mathrm{a}}$ & .520 & .507 & 2.533 \\
\hline
\end{tabular}

Based on the test results in the table above, R-Square value or determination of 0.520 is obtained, this shows that the contribution of the influence between learning motivation and teacher teaching style simultaneously on student learning achievement by $52.0 \%$, while the remaining $48.0 \%$ is influenced by other factors not examined.

To test the hypotheses of variable learning motivation (X1) and teacher teaching style (X2) on student learning achievement (Y), the statistical test $\mathrm{t}$ (partial test) was performed. The results of data processing using SPSS version 26, with the following results: 
Table 6

T-Test Results Variable Learning Motivation (X1)

Coefficients $^{\mathrm{a}}$

\begin{tabular}{|c|c|c|c|c|c|c|}
\hline \multirow{2}{*}{\multicolumn{2}{|c|}{ Model }} & \multicolumn{2}{|c|}{$\begin{array}{l}\text { Unstandardized } \\
\text { Coefficients }\end{array}$} & \multirow{2}{*}{$\begin{array}{c}\text { Standardized } \\
\text { Coefficients } \\
\text { Beta }\end{array}$} & \multirow[b]{2}{*}{$\mathrm{t}$} & \multirow[b]{2}{*}{ Sig. } \\
\hline & & B & Std. Error & & & \\
\hline \multirow[t]{2}{*}{1} & (Constant) & 14.987 & 3.273 & & 4.579 & .000 \\
\hline & Learning Motivation (X1) & .634 & .085 & .654 & 7.428 & .000 \\
\hline
\end{tabular}

Based on the test results in the above table, the value of $t_{\text {count }}>t_{\text {table }}$ or $(7.428>1.993)$ is also strengthened by the value of $\rho$ value $<$ Sig. 0.05 or $(0.000<0.05)$. Thus, $\mathrm{H} 0$ is rejected and $\mathrm{H} 1$ is accepted, this shows that there is a positive and partially significant effect between learning motivation on student learning achievement

Table 7.

T-Test Results Variable Teacher Teaching Style (X2)

Coefficients $^{\mathrm{a}}$

\begin{tabular}{|c|c|c|c|c|c|c|}
\hline \multirow{2}{*}{\multicolumn{2}{|c|}{ Model }} & \multicolumn{2}{|c|}{$\begin{array}{l}\text { Unstandardized } \\
\text { Coefficients }\end{array}$} & \multirow{3}{*}{$\begin{array}{c}\text { Standardized } \\
\text { Coefficients } \\
\text { Beta } \\
\end{array}$} & \multirow{3}{*}{$\frac{\mathrm{t}}{6701}$} & \multirow{3}{*}{$\begin{array}{c}\text { Sig. } \\
.000\end{array}$} \\
\hline & & B & Std. Error & & & \\
\hline \multirow[t]{2}{*}{1} & (Constant) & 20.022 & 2.988 & & & \\
\hline & $\begin{array}{l}\text { Teacher Teaching Style } \\
\text { (X2) }\end{array}$ & .494 & .076 & .600 & 6.454 & .000 \\
\hline
\end{tabular}

a. Dependent Variable: Student Learning Achievment (Y)

Based on the test results in the table above we get the value of $t_{\text {count }}>t_{\text {table }}$ or $(6.454>1.993)$, it is also strengthened by $\rho$ value $<$ Sig. 0.05 or $(0,000<0.05)$. Thus, $\mathrm{H} 0$ is rejected and H2 is accepted, this shows that there is a positive and partially significant effect between teacher teaching style on student achievement.

To test the effect of variable learning motivation and teacher teaching style simultaneously on Student Learning Achievement in MA Muhammadiyah is carried out by statistical F test (simultaneous test) with a significance of $5 \%$.

Table 8

Simultaneous Hypothesis (F-Test Results)

ANOVA $^{\mathrm{a}}$

\begin{tabular}{llr|r|r|r|r}
\hline \multicolumn{1}{l}{ Model } & \multicolumn{1}{c}{ Sum of Squares } & \multicolumn{1}{c}{ df } & Mean Square & \multicolumn{1}{c}{ F } & \multicolumn{1}{c}{ Sig. } \\
\hline \multirow{2}{*}{1} & Regression & 506.992 & 2 & 253.496 & 39.505 & $.000^{\mathrm{b}}$ \\
\cline { 2 - 7 } & Residual & 468.429 & 73 & 6.417 & & \\
\cline { 2 - 7 } & Total & 975.421 & 75 & & & \\
\hline
\end{tabular}

a. Dependent Variable: Student Learning Achievment (Y)

b. Predictors: (Constant), Teacher Teaching Style (X2), Learning Motivation(X1)

Based on the test results in the above table, the calculated $F_{\text {count }}>F_{\text {table }}$ or $(39.505>2.730)$ can be strengthened with $\rho$ value $<$ Sig. 0.05 or $(0,000<0.05)$. Thus, $\mathrm{H} 0$ is rejected and $\mathrm{H} 3$ is accepted, this shows that there is a positive and significant effect simultaneously between learning motivation and teacher teaching style on learning achievement of MA Muhammadiyah students. 


\author{
182 Pinisi Discretion Review \\ Volume 2, Issue 2, March, 2019 Page. 177- 184
}

\title{
CONCLUSION
}

Based on the research results learning motivation has a positive and significant effect on student learning achievement with a magnitude of influence of $42.7 \%$. Hypothesis testing obtained $t_{\text {count }}>t_{\text {table }}$ or $(7.428>1.993)$. Teacher teaching style has a positive and significant effect on student achievement with the magnitude of influence of $36.0 \%$. Hypothesis testing obtained $t_{\text {count }}>t_{\text {table }}$ or $(6.454>1.993)$. Teacher motivation and teaching style has a positive and significant effect on student achievement with a regression equation $\mathrm{Y}=10.474+0.454 \mathrm{X} 1+$ $0.293 \mathrm{X} 2$. The higher the learning motivation and teacher teaching style, the student learning achievement will also increase. The amount of influence is $52.0 \%$ while the remaining $48.0 \%$ is influenced by other factors. Hypothesis testing obtained the value of $F_{\text {count }}>F_{\text {table }}$ or (39.505> 2.730 ), this is also reinforced by the probability of $0,000<0.05$. Thus $\mathrm{H} 0$ is rejected and $\mathrm{H} 3$ is accepted. This means that there is a positive and significant effect simultaneously between learning motivation and teacher teaching style on student achievement in the MA Muhammadiyah

\section{REFERENCES}

Arhas, S. H. (2018). Metode Pembelajaran Black Knight. Apa? Mengapa? dan Bagaimana? Jurnal Ad'ministrare, 5(2), 165-172.

Azhar, A. (2008). Media Pembelajaran. Meedia Pembelajaran. https://doi.org/media pembelajaran

Hamdu, G., \& Agustina, L. (2011). Pengaruh Motivasi Belajar Terhadap Prestasi Bejalar IPA Di Sekolah Dasar. Jurnal Penelitian Pendidikan.

Hamid, A. (2017). Guru Professional. Guru Profesional.

Hendri, E. (2010). Guru Berkualitas: Profesional dan Cerdas Emosi. Jurnal Saung Guru.

Hernawan, A. H., Permasih, \& Dewi, L. (2008). Panduan Pengembangan Bahan Ajar. In Depdiknas Jakarta.

Hidayat, A. (2017). Cara Hitung Rumus Slovin Besar Sampel.

Idzhar, A. (2016). Peranan Guru dalam Meningkatkan Motivasi Belajar Siswa. Jurnal Office, 2(2), 221-228.

Kartowagiran, B. (2006). Kinerja Guru Profesional. In Transportation. https://doi.org/10.1002/ejoc.201200111

Laelasari, L. (2013). Upaya Menjadi Guru Profesional. Edunomic, Jurnal Ilmiah Pendidikan Ekonomi.

Prasetya, J. T., \& Ahmadi, A. (2005). Strategi belajar mengajar. Bandung: CV.

Qayyum, Q., Akib, H., \& Darwis, M. (2019). Pengaruh Partisipasi dalam Organisasi terhadap Prestasi Belajar Mahasiswa Fakultas Ilmu Sosial Universitas Negeri Makassar. UNIVERSITAS NEGERI MAKASSAR.

Rusman. (2012). Model-model Pembelajaran Mengembangkan Profesionalisme Guru. In Jakarta: Rajawali Pers.

S.Winataputra, U. (2006). Hakikat Belajar dan Pembelajaran. Belajar dan Pembelajaran. 
Saragih, A. H. (2008). Kompetensi Minimal Seorang Guru Dalam Mengajar. Jurnal Tabularasa.

Shabir, M. U. (2009). Kedudukan Guru Sebagai Pendidik: (Tugas dan Tanggung Jawab, Hak dan Kewajiban, dan Kompetensi Guru). Auladuna.

Sudrajat. (2015). Strategi pembelajaran. Statewide Agricultural Land Use Baseline 2015. https://doi.org/10.1371/journal.ppat.1000117

Suprianto, S., Arhas, S. H., \& Salam, R. (2018). Pengaruh Media Pembelajaran dan Pengelolaan Kelas terhadap Prestasi Belajar Siswa di SMK Negeri Kecamatan Tanete Riattang, Kabupaten Bone. Jurnal Ad'ministrare, 5(2), 137-146.

Suyanto, \& Jihad, A. (2013). MENJADI GURU PROFESIONAL: Strategi Meningkatkan Kualifikasi dan Kualitas Guru di Era Global. In Penerbit Erlangga.

Westri Setyo Lestari1, Herawati Susilo2, P. S. (2017). Pengembangan Bahan Ajar Tematik. Jurnal Pendidikan.

Yaumi, M. (2018). Media dan Teknologi Pembelajaran. In Jakarta.

Yuslaini, Y. (2012). Kemahiran Guru Abad Ke-21. Minda Pendidik. 